\title{
THE INFLUENCE OF THE ASH FROM THE BIOMASS ON THE POWER BOILER POLLUTION
}

\author{
Alina Kowalczyk-Juśko ${ }^{1}$ \\ 1 University of Life Sciences in Lublin, Faculty of Production Engineering, Department of Environmental \\ Engineering and Geodesy, Leszczyńskiego 7, 20-069 Lublin, Poland, e-mail: alina.jusko@up.lublin.pl
}

Received: 2017.08 .15

Accepted: 2017.10.01

Published: 2017.11.01

\begin{abstract}
Manufacturing units, which use biomass for combustion and co-firing, are obliged to gradually increase the amount of biomass from agricultural sources in place of timber biomass from forests. Many different species of trees that grow on arable land, bushes, grasses or perennials can be used for energy purposes. A huge variety of plants that give biomass useful in the power industry, is connected with a large diversity of physical characteristics (hardness, specific gravity, moisture content, porosity) and chemical composition. It significantly affects not only the calorific value of biomass but also the condition of the boilers in which it is burnt. This paper presents the results of the research concerning the influence of the process of combustion biomass from seven plant species on the boilers fouling on the basis of ash chemical composition. The indicators used for the analysis were as follows: boilers slagging, the tendency of fuel to form impurities, sintering and agglomeration. A significant variation in the content of alkalies was shown that cause the formation of sediment on the boilers heating surfaces. The smallest risk of heating boilers fouling is associated with perennial grasses incineration, especially the ones from the Miscanthus species that contain significant quantities of silicon monoxide, which is responsible for the heating surfaces erosion. The usage of polycarpic plants, such as Virginia mallow or Jerusalem artichoke, may cause pollution deposition and reduce the efficiency of boilers to the greatest degree. Because the biomass of different plant species exhibits the diversity of energy parameters and tendencies to foul boilers, there is a need to select the material to the combustion carefully. Moreover, blends of biomass raw materials (or biomass with coal) should be composed so that they are adapted to the boiler parameters and to the conditions of the combustion process.
\end{abstract}

Keywords: biomass, combustion, slagging, fouling

\section{INTRODUCTION}

In Poland, the most often used technologies of biomass energy are [Kubica 2007]:

- direct combustion of biomass - sliced, crushed or compact (pellets, briquettes, bales),

- direct co-firing with coal with the use of conventional boilers,

- indirect co-firing with coal (initial biomass gasification and then co-firing of the produced gas).

In this way electricity can be generated; alternatively, electricity and heat can be simultaneously produced in co-generation systems - CHP (combined heat and power).
The chemical composition of biomass depends on genetic factors and physiological characteristics of different plant species and varieties, as well as on the development phase, the part of the plant, fertilization and chemical protection, soil nutrient availability, the term and method of harvest, transport, storage and other factors [Monti et al. 2008, Vasillev et al. 2014b]. This often causes the divergence of the results obtained in the research carried out on the same species. The knowledge of the characteristics of the plant material is important from the energy point of view, since each parameter affects the efficiency of biomass combustion [Van Loo, Koppejan 2008, Villeneuve et al. 2012]. 
One of the most important parameters in the assessment of the fuels produced from biomass, which are listed by McKendry [2002], is the ash content (minerals) and the share of alkaline oxides in it. A significant proportion of alkaline metals (e.g. $\mathrm{Ca}, \mathrm{K}, \mathrm{Na}$ ) and the presence of chlorine may cause occurrence of adverse phenomena, such as slagging and accelerated corrosion of certain metal elements (chlorine and chloride corrosion). Co-firing is an effective way to use biomass; however, only temporarily. More efficient technologies are gasification combined with gas-steam systems and the usage of gas or ethanol from biomass to power efficient fuel cells. Golec et al. [2007] showed such advantages of co-firing as: the possibility of using biomass in large scale (large boilers), stabilization of combustion by burning coal, less emissions of $\mathrm{SO}_{2}$, $\mathrm{NO}_{x}$, and $\mathrm{CO}_{2}$, boiler flexibility as well as the independence of the electricity production from the biomass availability. The main disadvantages are: difficulty with delivery and preparation (drying, fragmentation) of the sufficient amount of biomass and its high price, limited productivity and efficiency of the boiler, the increased risk of selffire or explosion, the side effects of the co-firing associated with the ash from biomass composition (slagging, fouling). Kordylewski and Tatarek [2012] indicated such disadvantages of biomass co-firing in ash boilers as: high transport costs, impediments occurring in the course of boiler exploitation due to biomass sedimentation, formation of overhangings, reduced milling capacity of the mills, intensified processes of sintering and heating surface corrosion. The research indicates that the origin of raw material (plant species) and the biomass moisture significantly affects a number of parameters relevant to the energy processes [Gradziuk et al. 2003, Jenkins et al. 1998, Mółka, Łapczyńska-Kordon 2011, Niedziółka, Zuchniarz 2006].

The method of fuel preparation, technique and combustion conditions and the afore-mentioned factors that form the chemical composition of biomass also affect the quantity and composition of ash that is important for energy units [Vasiliev et al. 2014b]. The proportion of alkaline ash components $\left(\mathrm{Fe}_{2} \mathrm{O}_{3}, \mathrm{CaO}, \mathrm{MgO}, \mathrm{Na}_{2} \mathrm{O}, \mathrm{K}_{2} \mathrm{O}\right.$ and $\left.\mathrm{P}_{2} \mathrm{O}_{5}\right)$ and the acidic ones $\left(\mathrm{SiO}_{2}, \mathrm{Al}_{2} \mathrm{O}_{3}\right.$ and $\left.\mathrm{TiO}_{2}\right)$ is an indicator that characterizes the tendency of the ash to form sediments. High content of alkalies and chlorine can lead to the corrosion of energy devices [Kowalczyk-Juśko 2009]. The high content of alkaline oxides in the ash indicates that there is a danger of sediments accretion on the heating devices. The aim of the research was to estimate the influence of plant biomass on the boilers fouling on the basis of ash chemical composition.

\section{MATERIALS AND METHODS}

The research material involved the biomass of seven energetic plant species:

- perennial grasses: Miscanthus sacchariflorus and prairie cordgrass (Spartina pectinata Bosc ex Link),

- perennials: Virginia mallow (Sida hermaphrodita Rusby) and Jerusalem artichoke (Helianthus tuberosus L.),

- annual grasses: corn (Zea mays L.) and sweet sorghum (Sorghum bicolor Moench),

- shrub: multiflora rose(Rosa multiflora Thunb.).

The biomass of the tested plants was burned at $600^{\circ} \mathrm{C}$ and the ash was analyzed by the elemental composition of the spectrometric method.

In order to characterize fuels in terms of their tendency to slag and pollute the heating surfaces of the boiler (forming the sediments), various indices are used, most often based on the proportions of acidic and alkaline oxides in the ash [CoalTech 2007, Ściążko et al. 2007, Vassilev et al. 2014a, Viana et al. 2012]. The following indices were used:

1. $c_{m}$ index:

$c_{m}=\frac{\mathrm{Fe}_{2} \mathrm{O}_{3}+\mathrm{CaO}+\mathrm{MgO}+\mathrm{Na}_{2} \mathrm{O}+\mathrm{K}_{2} \mathrm{O}+\mathrm{P}_{2} \mathrm{O}_{5}}{\mathrm{SiO}_{2}+\mathrm{Al}_{2} \mathrm{O}_{3}+\mathrm{Ti}_{2} \mathrm{O}}$

This is the ratio of alkaline to acidic oxides [Ściążko et al. 2007].

2. Base to acid index:

$$
B / A=\frac{\mathrm{Fe}_{2} \mathrm{O}_{3}+\mathrm{CaO}+\mathrm{MgO}+\mathrm{Na}_{2} \mathrm{O}+\mathrm{K}_{2} \mathrm{O}}{\mathrm{SiO}_{2}+\mathrm{Al}_{2} \mathrm{O}_{3}+\mathrm{Ti}_{2} \mathrm{O}}
$$

If $B / A$ ratio $<0.75$, impurities can be expected [Viana et al. 2012]. If $B / A<0.4$ or $B / A>0.7$, the tendency towards sedimentation is low, but if $0.7>B / A>0.4-$ high [CoalTech 2007].

3. Simplified $R_{(b / a)}$ index:

$$
R_{(b / a)}=\frac{\mathrm{Fe}_{2} \mathrm{O}_{3}+\mathrm{CaO}+\mathrm{MgO}}{\mathrm{SiO}_{2}}
$$

The lower the value of $R_{(b / a)}$, the higher the melting and flowing temperature of the ash 
and hence the lower the risk of slagging. At $R_{\text {(b/a) }}<0.15$ these temperatures exceed $1600^{\circ} \mathrm{C}$ [Ściążko et al. 2007].

4. $S_{R}$ index:

$$
S_{R}=\frac{\mathrm{SiO}_{2} \times 100}{\mathrm{SiO}_{2}+\mathrm{Fe}_{2} \mathrm{O}_{3}+\mathrm{CaO}+\mathrm{MgO}}
$$

The high value of $S_{R}$ index means high slag viscosity and thus a low slagging tendency. If $S_{R}$ $>72$ - slag has a low slagging tendency, if $72 \geq S_{R}$ $>65$ - acerage, if $S_{R} \mathrm{R} \leq 65$ - low [Ściążko et al. 2007]. If $S_{R}$ is $72-80$, the tendency to form impurities is low, if $S_{R}$ ranges between 65-73 - average and 50-65 - very high [CoalTech 2007].

5. Fu index:

$$
F_{u}=\left(N a_{2} \mathrm{O}+\mathrm{K}_{2} \mathrm{O}\right) \cdot c_{m}
$$

The $F_{u}$ index determines the tendency of the fuel to form and subsequently sinter the contaminants of the heating surfaces and the tendency to form deposits that initiate slagging. If $\mathrm{Fu} \leq 0.6$, then fuel is not prone to pollution, if $0.6<\mathrm{Fu}$ $\leq 40$ - has a high propensity and if $\mathrm{Fu}>40$ - very high propensity to create and sinter contaminants [Ściążko et al. 2007].

6. The sum of iron and calcium oxides:

$$
\mathrm{Fe}+\mathrm{Ca}=\mathrm{Fe}_{2} \mathrm{O}_{3}+\mathrm{CaO}
$$

If the sum of $\mathrm{Fe}_{2} \mathrm{O}_{3}+\mathrm{CaO}$ does not exceed $10 \%$, then the fuel has a low tendency to form pollutants [CoalTech 2007].
7. The ratio of the iron oxides to calcium:

$$
\mathrm{IC}=\frac{\mathrm{Fe}_{2} \mathrm{O}_{3}}{\mathrm{CaO}}
$$

If the $I C<0.3$ or $I C>3.0$, then the tendency to form pollutants is low, if $0.3<I C<3.0-$ high [CoalTech 2007].

8. The sintering index:

$$
\mathrm{SI}=\frac{\mathrm{CaO}+\mathrm{MgO}}{\mathrm{Na}_{2} \mathrm{O}+\mathrm{K}_{2} \mathrm{O}}
$$

If $S I>2$, the risk of slagging is low, if $S I<2-$ high [Viana et al. 2012].

9. The agglomeration index:

$$
B A I=\frac{\mathrm{Fe}_{2} \mathrm{O}_{3}}{\mathrm{Na}_{2} \mathrm{O}+\mathrm{K}_{2} \mathrm{O}}
$$

It concerns the potential for sediment formation on fluidized beds. If $B A I<0.15$, then agglomerates are formed [Viana et al. 2012].

\section{RESULTS AND DISCUSSION}

In the authors' own studies significant differences in composition of the ash from biomass of particular energy plants were found (Table 1). There are three groups of species whose ash has similar composition: perennial grass (Miscan-

\begin{tabular}{|c|c|c|c|c|c|c|c|c|}
\hline Content & Symbol & \begin{tabular}{|c|}
$\begin{array}{c}\text { Miscanthus } \\
\text { sacchariflorus }\end{array}$ \\
\end{tabular} & $\begin{array}{c}\text { Spartina } \\
\text { pectinata }^{1}\end{array}$ & $\begin{array}{c}\text { Sida } \\
\text { hermaphrodita }^{1} \\
\end{array}$ & $\begin{array}{l}\text { Helianthus } \\
\text { tuberosus }^{1}\end{array}$ & \begin{tabular}{|c|} 
Rosa \\
multiflora $^{1}$ \\
\end{tabular} & Zea mays ${ }^{2}$ & $\begin{array}{c}\text { Sorghum } \\
\text { bicolor }^{3}\end{array}$ \\
\hline Ash & $A_{d}$ & 3.70 & 4.10 & 2.80 & 5.60 & 3.10 & 7.20 & 4.80 \\
\hline Silicon dioxide & $\mathrm{SiO}_{2}$ & 77.90 & 66.10 & 3.20 & 6.80 & 6.74 & 35.20 & 35.40 \\
\hline Iron & $\mathrm{Fe}_{2} \mathrm{O}_{3}$ & 1.33 & 0.98 & 0.76 & 0.51 & 1.69 & 0.82 & 2.20 \\
\hline Aluminium & $\mathrm{Al}_{2} \mathrm{O}_{3}$ & 2.06 & 0.85 & 0.48 & 0.46 & 0.81 & 0.44 & 0.36 \\
\hline Manganese & $\mathrm{Mn}_{3} \mathrm{O}_{4}$ & 0.09 & 0.10 & 0.05 & 0.05 & 0.09 & 0.06 & 0.05 \\
\hline Titanium & $\mathrm{TiO}_{2}$ & 0.06 & 0.04 & 0.04 & 0.02 & 0.04 & 0.04 & 0.02 \\
\hline Calcium & $\mathrm{CaO}$ & 8.35 & 14.30 & 35.70 & 18.80 & 32.00 & 6.82 & 6.62 \\
\hline Magnesium & $\mathrm{MgO}$ & 0.82 & 2.30 & 5.34 & 1.06 & 7.85 & 2.30 & 2.45 \\
\hline Sulphur & $\mathrm{SO}_{3}$ & 2.21 & 4.63 & 2.42 & 1.85 & 3.50 & 2.52 & 2.32 \\
\hline Phosphorus & $\mathrm{P}_{2} \mathrm{O}_{5}$ & 1.87 & 2.96 & 4.85 & 3.69 & 16.50 & 7.31 & 9.30 \\
\hline Sodium & $\mathrm{Na}_{2} \mathrm{O}$ & 0.46 & 0.88 & 0.80 & 0.54 & 0.82 & 0.08 & 0.05 \\
\hline Potassium & $\mathrm{K}_{2} \mathrm{O}$ & 2.66 & 4.97 & 14.30 & 35.80 & 13.00 & 38.70 & 35.90 \\
\hline Barium & $\mathrm{BaO}$ & 0.02 & 0.03 & 0.03 & 0.04 & 0.04 & 0.01 & 0.01 \\
\hline Strontium & SrO & 0.02 & 0.04 & 0.10 & 0.09 & 0.12 & 0.02 & 0.02 \\
\hline Chlorides & $\mathrm{Cl}$ & 0.00 & 0.25 & 0.24 & 4.74 & 1.00 & 2.10 & 2.81 \\
\hline Carbonates & $\mathrm{CO}_{2}$ & 1.22 & 0.72 & 30.70 & 24.60 & 15.40 & 2.59 & 1.56 \\
\hline
\end{tabular}
thus sacchariflorus and Prairie cordgrass), annual grasses (corn and sorghum), perennials (Virginia mallow and Jerusalem artichoke). The ash from the biomass of the multiflora rose was not in-

Table 1. Content and composition of the plant biomass ash [\%]

Source: 1 - Kowalczyk-Juśko 2009; 2 - Kowalczyk-Juśko at al. 2015a; 3 - Kowalczyk-Juśko et al. 2015b 
cluded in any of these groups. The sum of alkaline oxides constitutes an important parameter for ash evaluation. Their high content was recorded in ash obtained from perennials, roses and bedding grasses, but the share of individual elements in this sum varied for different species. Potassium prevailed in the ash from corn and sorghum $(38.7-35.9 \%)$, it was quite similar in the ash from Jerusalem artichoke (35.8\%), while in mallow the dominating element was calcium (35.7\%).

High concentrations of $\mathrm{CaO}$ and $\mathrm{K}_{2} \mathrm{O}$ were also reported in the ash from the Arudno donax and Cynara cardunculus biomass [Monti et al. 2008]. Kalembasa [2006] found that the highest concentration of calcium in the ash from the biomass of the Miscanthus sinensis and the Virginia mallow, silica and potassium oxide prevailed accounting for about $70 \%$ of the ash and the $\mathrm{P}_{2} \mathrm{O}_{5}$ content was about 10\% [Baxter et al. 2014]. There is a noticeable negative correlation between $\mathrm{SiO}_{2}$ and $\mathrm{K}_{2} \mathrm{O}$ content. Baxter et al. [2014] noted that while the Giant miscant (Miscanthus $\times$ giganteus) harvest was delayed, the silica content increased and the potassium oxide decreased. It was also noted that the content of oxides may depend on the organ of the plant. The ash from Giant miscant leaves was characterized by lower $\mathrm{K}_{2} \mathrm{O}$ and higher $\mathrm{CaO}$ content compared to the ash received from blades burning [Baxter et al. 2014].

In the authors' own research, the ratio of alkaline to acidic components, which characterized the ash deposition tendency, was the lowest in the case of perennial grasses, and many times higher in the case of Virginia mallow. In the research of Baxter et al. [2014] it was shown that the ratio of alkaline to acidic components in the leaves of Giant miscant was in the range $0.7-1.3$, while in the stems the proportions were different and the
$\mathrm{B} / \mathrm{A}$ ratio amounted to $1.3-3.2$. In addition, the parabolic relationship between ash melting temperatures and the ratio of alkaline to acidic components is suggested.

The ash from the biomass of Miscanthus sacchariflorus and prairie cordgrass (Spartina pectinata) was characterized by a small tendency to form pollutants and sediments which has been determined by using various indicators (Table 2). At the same time, a very high tendency for sintering, slagging and sedimentation on fluidized beds was observed in the case of the ash from Virginia mallow and Jerusalem artichoke. This is demonstrated by the values of Fu, SI and BAI that are much higher.

The statistical analysis confirmed the significant differences in how the ashes form pollutants in three groups: perennial grasses, annual grasses and perennials, which were previously observed at the level of chemical composition. Interesting$1 y$, the common features are not dependent on the botanical family, but rather on the type of growth and development, as evidenced by the fact that Virginia mallow and Jerusalem artichoke, which belong to different botanical families, affect the heating devices in a similar way.

\section{CONCLUSIONS}

1. Differentiation of the composition of the ash from biomass of particular plant species is associated with different risks of heating devices surfaces contamination and damage (slagging, agglomeration, deposition, sintering, corrosion, erosion), which makes agricultural biomass impossible to be treated homogeneously.

2 . We can distinguish groups of species (not always based on botanical families, but rather on

Table 2. Slagging and fouling indices accounted for ashes from investigated biomass

\begin{tabular}{|c|c|c|c|c|c|c|c|}
\hline Index & $\begin{array}{c}\text { Miscanthus } \\
\text { sacchariflorus }\end{array}$ & $\begin{array}{c}\text { Spartina } \\
\text { pectinata }\end{array}$ & $\begin{array}{c}\text { Sida } \\
\text { hermaphrodita }\end{array}$ & $\begin{array}{c}\text { Helianthus } \\
\text { tuberosus }\end{array}$ & $\begin{array}{c}\text { Rosa } \\
\text { multiflora }\end{array}$ & $\begin{array}{c}\text { Sea mays } \\
\text { bicolor }\end{array}$ \\
\hline $\mathrm{C}_{\mathrm{m}}$ & $0.19 \mathrm{a}$ & $0.39 \mathrm{a}$ & 16.60 & $8.30 \mathrm{c}$ & $9.47 \mathrm{c}$ & $1.57 \mathrm{~b}$ & $1.58 \mathrm{~b}$ \\
\hline $\mathrm{B} / \mathrm{A}$ & $0.17 \mathrm{a}$ & $0.35 \mathrm{a}$ & 15.30 & $7.79 \mathrm{c}$ & $7.29 \mathrm{c}$ & $1.37 \mathrm{~b}$ & $1.32 \mathrm{~b}$ \\
\hline $\mathrm{R}_{\mathrm{b}} / \mathrm{a}$ & $0.13 \mathrm{a}$ & $0.27 \mathrm{a}$ & $13.06 \mathrm{c}$ & $3.00 \mathrm{~b}$ & $6.16 \mathrm{~b}$ & $0.28 \mathrm{a}$ & $0.32 \mathrm{a}$ \\
\hline $\mathrm{S}_{\mathrm{R}}$ & $88.12 \mathrm{a}$ & $78.99 \mathrm{a}$ & $7.11 \mathrm{c}$ & 25.03 & $13.96 \mathrm{~b}$ & $77.98 \mathrm{a}$ & $75.85 \mathrm{a}$ \\
\hline $\mathrm{F}_{\mathrm{u}}$ & $0.60 \mathrm{a}$ & $2.30 \mathrm{a}$ & $250.65 \mathrm{c}$ & $301.50 \mathrm{c}$ & $130.84 \mathrm{c}$ & $60.90 \mathrm{~b}$ & $56.79 \mathrm{~b}$ \\
\hline $\mathrm{Fe}+\mathrm{Ca}$ & $9.68 \mathrm{a}$ & $15.28 \mathrm{~b}$ & $36.46 \mathrm{c}$ & $19.31 \mathrm{~b}$ & $33.69 \mathrm{c}$ & $7.64 \mathrm{a}$ & $8.82 \mathrm{a}$ \\
\hline $\mathrm{IC}$ & $0.16 \mathrm{a}$ & $0.07 \mathrm{~b}$ & $0.02 \mathrm{~b}$ & $0.03 \mathrm{~b}$ & $0.05 \mathrm{~b}$ & $0.12 \mathrm{a}$ & $0.33 \mathrm{c}$ \\
\hline $\mathrm{SI}$ & $2.94 \mathrm{a}$ & $2.84 \mathrm{a}$ & $2.72 \mathrm{a}$ & $0.55 \mathrm{~b}$ & $2.88 \mathrm{a}$ & $0.24 \mathrm{~b}$ & $0.25 \mathrm{~b}$ \\
\hline $\mathrm{BAI}$ & $0.43 \mathrm{a}$ & $0.17 \mathrm{~b}$ & $0.05 \mathrm{c}$ & $0.01 \mathrm{c}$ & $0.12 \mathrm{~b}$ & $0.02 \mathrm{c}$ \\
\hline
\end{tabular}

Note: The same letters indicate the results that do not differ significantly at the level of 0.05 
growth and durability), with similar effects on heating devices. The smallest risk of slagging is associated with the incineration of perennial grasses (Miscanthus sacchariflorus and prairie cordgrass), while the largest is observed in the case of burning perennials (Jerusalem artichoke and Virginia mallow). Combustion of the grass biomass may involve the risk of the heating surfaces erosion due to the high silica content. On the other hand, the combustion of perennials increases the risk of chloride corrosion.

3. There is a great need to select the raw material for combustion carefully and to compose mixtures of biomass raw materials (or biomass with bituminous coal) that are adjusted to the boiler parameters and combustion process conditions.

\section{REFERENCES}

1. Baxter X.C., Darvell L.I., Jones J.M., Barraclough T., Yates N.Y., Shield I. 2014. Miscanthus combustion properties and variations. Fuel, 117, 851-869.

2. CoalTech. 2007. Coal Technology. Consultancy in Coal Utilisation Technology. http://www. coaltech.com.au/Slagging\&Fouling.html. Access: 14.08.2017.

3. Golec T., Szymczak J., Zaręba R. 2007. Doświadczenia eksploatacyjne zebrane przez Instytut Energetyki podczas współspalania biomasy w kotłach energetycznych. [In:] Ściążko M., Zuwała J., Pronobis M. (ed.). Współspalanie biomasy i paliw alternatywnych w energetyce. Instytut Chemicznej Przeróbki Węgla, Politechnika Śląska, Zabrze, 183-191.

4. Gradziuk P., Grzybek A., Kowalczyk K, Kościk B. 2003. Biopaliwa, Wyd. Wieś Jutra, Warszawa.

5. Jenkins B.M., Baxter L.L., Miles Jr. T.R., Miles T.R. 1998. Combustion properties of biomass. Fuel Processing Technology, 54, 17-46.

6. Kalembasa D. 2006. Ilość i skład chemiczny popiołu z biomasy roślin energetycznych. Acta Agrophysica, 7(4), 909-914.

7. Kordylewski W., Tatarek A. 2012. Wybrane właściwości toryfikatów $\mathrm{z}$ krajowych i importowanych biomas. Archiwum Spalania, 12(3), 109-116.

8. Kowalczyk-Juśko A. 2009. Popiół z różnych roślin energetycznych. Proceedings of ECOpole, 3(1), 159-164.
9. Kowalczyk-Juśko A., Marczuk A., Dach J., Szmigielski M., Zarajczyk J., Jóźwiakowski K., Kowalczuk J., Andrejko D., Ślaska-Grzywna B., Leszczyński N. 2015a. Thermochemical and biochemical maize biomass conversion for power engineering. Przemysł Chemiczny 94/2, 178-181.

10. Kowalczyk-Juśko A., Kościk B., Jóźwiakowski K., Marczuk A., Zarajczyk J., Kowalczuk J., Szmigielski M., Sagan A. 2015b. Effects of biochemical and thermochemical conversion of sorghum biomass to usable energy. Przemysł Chemiczny 94/10, 1838-1840.

11. Kubica K. 2007. Energetyczne wykorzystanie biomasy - uwarunkowania techniczno-technologiczne. Biuletyn Ekologiczny, 3(163), 3-7.

12. McKendry P. 2002. Energy production from biomass (part 1): overview of biomass. Bioresource Technology, 83, 37-46.

13. Mółka J., Łapczyńska-Kordon B. 2011. Właściwości energetyczne wybranych gatunków biomasy. Inżyniera Rolnicza, 6(131), 141-146.

14. Monti A., Di Virgilio N., Venturi G. 2008. Mineral composition and ash content of six major energy crops. Biomass and Bioenergy, 32, 216-232.

15. Niedziółka I., Zuchniarz A. 2006. Analiza energetyczna wybranych rodzajów biomasy pochodzenia roślinnego. MOTROL, 8A, 232-237.

16. Ściążko M., Zuwała J., Pronobis M., Winnicka G. 2007. Problemy związane ze współspalaniem biomasy w kotłach energetycznych. [In:] Ściążko M., Zuwała J., Pronobis M. (ed.). Współspalanie biomasy i paliw alternatywnych w energetyce, Instytut Chemicznej Przeróbki Węgla, Politechnika Śląska, Zabrze, 17-42.

17. Van Loo S., Koppejan J. (ed.). 2008. The Handbook of Biomass Combustion and Co-firing. Earthscan, Londyn.

18. Vassilev S.V., Baxter D., Vassileva C.G. 2014a. An overview of the behaviour of biomass during combustion: Part II. Ash fusion and ash formation mechanisms of biomass types. Fuel, 117, 152-183.

19. Vassilev S.V., Vassileva C.G., Baxter D. 2014 b. Trace element concentrations and associations in some biomass ashes. Fuel, 129, 292-313.

20. Viana H., Vega-Nieva D.J., Ortiz Torres L., Lousada J., Aranha J. 2012. Fuel characterization and biomass combustion properties of selected native woody shrub species from central Portugal and NW Spain. Fuel, 102, 737-745.

21. Villeneuve J., Palacios J.H., Savoie P., Godbout S. 2012. A critical review of emission standards and regulations regarding biomass combustion in small scale units (<3 MW). Bioresource Technology, 111, 1-11.

Pracę dofinansowano ze środkówWojewódzkiego Funduszu Ochrony Środowiska i Gospodarki Wodnej w Lublinie. 